6234

Research Note

Journal of Extension Education

Vol. 31 No. 1, 2019

DOI:https://doi.org/10.26725/JEE.2019.1.31.6234-6239

\title{
Trends and Technological Skills Assessment of Flower Cultivation in the Southern Districts of Tamil Nadu
}

\section{S. Nazreen Hassan ${ }^{1}$ and S. Aravindh Kumar ${ }^{2}$}

\begin{abstract}
Flowers are used by people of all walks of life starting from birth to death and have become an integral part of human living in our society. The demand for flowers has been increasing ever year. Commercial cultivation of flowers has assured importance in recent times. A study was conducted to find out the trend in flower cultivation in the southern districts of Kanyakumari and Tirunelveli in Tamil Nadu. An increase in area under flower cultivation was observed in both the districts. A majority of the farmers had a farming experience of two to four years, had followed either nipping or pruning and less than one fourth of the farmers followed regular rejuvenation.
\end{abstract}

Keywords: Jasmine; Rose; Nerium; Technological skill assessment;Tirunelveli; Kanyakumari; Tamil Nadu

The area under cultivation of flowers in India had increased from 191 thousand hectares in 2010-11 to 309 thousand hectares in 2016-17. Commercial floriculture is becoming an important industry in India. Floriculture is now commercially followed in several states with Andhra Pradesh (24\%), Tamil Nadu (20\%) Karnataka (13\%), having gone ahead of other producing states the area and production of flowers for the last five years has increased from 28.71 thousand hectares in 2012-13 to 32.29 thousand hectares in 201617. An attempt has been made to find out the trend in flower cultivation with the specific objective of finding out the Technological Skill in cultivation of flowers in the southern districts of Kanyakumari and Tirunelveli in Tamil Nadu.

\section{METHODOLOGY}

The study was undertaken in Tirunelveli and Kanyakumari districts of Tamil Nadu. These districts were purposively selected for their high area under cultivation of traditional flowers.

Four blocks were selected from the two districts based on maximum area under cultivation. Accordingly, Tenkasi \& Sankarankovil blocks, of Tirunelveli district, and Thovalai Agastheeswaram blocks of Kanyakumari district were selected for the study. Eighty four farmers were randomly selected and they formed the sample of the study.

1. Assistant Professor and 2. P.G. Scholar, Agricultural College \& Research Institute, (TNAU) Killikulam - 628252

Received : 10-01-2019; Accepted : 28-01-2019 
Trends and Technological Skills Assessment of Flower Cultivation in the Southern Districts of Tamil Nadu

\section{FINDINGS AND DISCUSSION}

\section{Trend in Flower Cultivation}

In Tamil Nadu, flowers are produced in an area of about 32,400 hectares with the production of 416.63 thousand MT (Jasmine, Chrysanthemum, Marigold, Rose, Crossandra and Nerium). In this, cut rose is grown in 600 ha area with a production of 795 lakh stems (NHB, 2013). Jasmine, which covers an area of 15,584 ha with a production of $1,42,397$ tones contributes a major share to the floriculture trade.

Analysis of area \& production under major flowers shows an increasing trend compared to the previous years. The major varieties grown in the area are Ramnad local in Jasmine, Prajwal and local varieties in tuberose, Edward Rose, Andhra Rose, button rose and Mysore Rose in rose cultivation and local Red and white varieties in Nerium.

There is a shift from the area under jasmine cultivation which was 221 ha in 2010 to $129.5 \mathrm{ha}$. There was 18.5 per cent decrease in area under jasmine in Kanyakumari district which is replaced by tuberose, nerium and chrysanthemum. The area under cultivation of different crops in the study area is provided in Table1.

In Kanyakumari district, the area under Nerium had increased by 15.5 percent in 2016-17. The reasons projected by the farmers were lesser cost of cultivation, lesser perishability and flowering throughout the year. An increase in area was also observed in Tirunelveli district. The farmers prefer to grow annual crops rather than perennial crops. The preference is due to the high price it fetches during festival season in the nearby state of Kerala. The tuberose variety grown in the area is Prajwal. The seed material for jasmine is received from Ramnad. The area under rose cultivation is shifted to marigold and tuberose. Nerium occupies an area upto $40 \mathrm{ha}$. The production of flowers in Tirunelveli was 22560 tonnes and in Kanyakumari district it was 2800 tonnes. Bagyajanani (2016) had reported that Tirunelveli district ranked first in area under jasmine cultivation during 201112.

The socio -economic profile of flower growers in southern districts of Tamil Nadu is given in Table 2.

Table 1.

Area under Major Flowers in the Study Area

$(n=84)$

\begin{tabular}{|c|c|c|c|c|c|c|c|c|c|c|c|}
\hline \multirow{2}{*}{\begin{tabular}{c}
\multirow{2}{*}{ Sl. } \\
No
\end{tabular}} & \multirow{8}{*}{ Districts } & \multicolumn{2}{|c|}{ Jasmine } & \multicolumn{2}{c|}{ Rose } & \multicolumn{2}{c|}{ Mullai } & \multicolumn{2}{c|}{ Tuberose } & \multicolumn{2}{c|}{ Nerium } \\
\cline { 3 - 13 } & & $2015-$ & $2016-$ & $2015-$ & $2016-$ & $2015-$ & $2016-$ & $2015-$ & $2016-$ & $2015-$ & $2016-$ \\
16 & 17 & 16 & 17 & 16 & 17 & 16 & 17 & 16 & 17 \\
\hline 1 & Kanyakumari & 159 & 129.5 & 3 & 3 & 1 & 1 & 33 & 40 & 21 & 36.54 \\
\hline 2 & Tirunelveli & 1048 & 1696 & 13.07 & 52 & 73 & 73 & 50 & 72 & 38 & 69 \\
\hline
\end{tabular}


Table 2.

Socio -economic profile of Flower Growers in Southern Districts of Tamil Nadu

$(n=84)$

\begin{tabular}{|c|c|c|c|}
\hline $\begin{array}{l}\text { SI. } \\
\text { No }\end{array}$ & Category & Number & Percentage \\
\hline \multirow[t]{6}{*}{1} & Age Years & & \\
\hline & $\leq 45$ years & 26 & 30.95 \\
\hline & $46-50$ years & 36 & 42.86 \\
\hline & $51-60$ years & 14 & 16.67 \\
\hline & 61-69 years & 6 & 7.14 \\
\hline & $\geq 70$ years & 2 & 2.38 \\
\hline \multirow[t]{5}{*}{2} & Education & & \\
\hline & Illiterate & 2 & 2.38 \\
\hline & Primary & 40 & 47.62 \\
\hline & High School & 16 & 19.05 \\
\hline & Collegiate & 26 & 30.95 \\
\hline \multirow[t]{3}{*}{3} & Occupation & & \\
\hline & Farming alone & 82 & 97.62 \\
\hline & Farming +others & 2 & 2.38 \\
\hline \multirow[t]{5}{*}{4} & Area under crops & & \\
\hline & Upto $1 \mathrm{ac}$ & 34 & 40.48 \\
\hline & $1.1-2 \mathrm{ac}$ & 16 & 19.05 \\
\hline & $2.5-3 \mathrm{ac}$ & 20 & 23.81 \\
\hline & $3.1-5 \mathrm{ac}$ & 14 & 16.67 \\
\hline \multirow[t]{12}{*}{5} & \multicolumn{3}{|c|}{$\begin{array}{l}\text { Percentage share of area under flowers } \\
\text { to total area in farmers holdings }\end{array}$} \\
\hline & $100.00 \%$ & 42 & 50.00 \\
\hline & $83.00 \%$ & 8 & 9.52 \\
\hline & $66.66 \%$ & 2 & 2.38 \\
\hline & $50.00 \%$ & 8 & 9.52 \\
\hline & $40.00 \%$ & 6 & 7.14 \\
\hline & $33.33 \%$ & 4 & 4.76 \\
\hline & $25.00 \%$ & 4 & 4.76 \\
\hline & $24.00 \%$ & 2 & 2.38 \\
\hline & $20.00 \%$ & 4 & 4.76 \\
\hline & $17.00 \%$ & 2 & 2.38 \\
\hline & $10.00 \%$ & 2 & 2.38 \\
\hline
\end{tabular}

\begin{tabular}{|c|c|c|c|}
\hline $\begin{array}{l}\text { SI. } \\
\text { No }\end{array}$ & Category & Number & Percentage \\
\hline \multirow[t]{5}{*}{6} & Annual Income & & \\
\hline & $<1$ lakhs & 14 & 16.67 \\
\hline & 1 to 2 lakhs & 30 & 35.71 \\
\hline & 2 to 5 lakhs & 36 & 42.86 \\
\hline & $>5$ lakhs & 4 & 4.76 \\
\hline \multirow[t]{5}{*}{7} & \multicolumn{3}{|c|}{ Experience in flower cultivation } \\
\hline & $\begin{array}{l}\text { Less than one } \\
\text { year }\end{array}$ & 8 & 9.52 \\
\hline & 1-2 years & 22 & 26.19 \\
\hline & 2- 4 years & 38 & 45.24 \\
\hline & $\begin{array}{l}5 \text { years and } \\
\text { above }\end{array}$ & 16 & 19.05 \\
\hline \multirow[t]{3}{*}{8} & \multicolumn{3}{|l|}{ Trainings attended } \\
\hline & $\begin{array}{l}\text { Trainings } \\
\text { Attended }\end{array}$ & 48 & 57.14 \\
\hline & $\begin{array}{l}\text { Trainings related } \\
\text { to flower } \\
\text { cultivation }\end{array}$ & 8 & 16.66 \\
\hline
\end{tabular}

Skill gap assessment in Flower Cultivation.

A skill gap assessment in flower cultivation was performed and the results are presented in Table 3.

Majority of flower farmers contacted (33.33\%) had followed either pruning or nipping which was an important operation in increasing the yields of flowers. Mostly pruning is done in crops like jasmine and rose and nipping in annual crops like chrysanthemum and crossandra. Bio stimulants were used by 5.95 per cent of the flower growers. Top dressing is done by 19.05 per cent of the flower growers. Pest and disease incidence is taken care of by 34.52 per cent especially in jasmine. Major skill gap was observed in 
Trends and Technological Skills Assessment of Flower Cultivation in the Southern Districts of Tamil Nadu

Table 3.

Skill Gap Assessment in Flower Cultivation

$(n=84)$

\begin{tabular}{|c|l|c|c|}
\hline SI. No & \multicolumn{1}{|c|}{ Skills followed } & Number & Percentage \\
\hline 1 & Seed/seed material treatment & 2 & 2.38 \\
\hline 2 & Pruning/ Nipping that promotes flowering & 28 & 33.33 \\
\hline 3 & Biostimulants / Micro nutrient application & 5 & 5.95 \\
\hline 4 & Top dressing & 16 & 19.05 \\
\hline 5 & Management of pest and disease & 29 & 34.52 \\
\hline 6 & Regular rejuvenation for rose and jasmine & 18 & 21.43 \\
\hline 7 & Fertilizer Management & 22 & 26.19 \\
\hline 8 & Bio fertilizer application & 7 & 8.33 \\
\hline 9 & Others & 2 & 2.38 \\
\hline
\end{tabular}

seed material treatment and application of bio stimulant or micronutrient. Bio fertilizer application is followed only by 8.33 percent. Less than one fourth of the farmers (21.43\%) followed regular rejuvenation which is much required in increasing the production of flower crops like rose and jasmine.

Constraints Faced by the Flower Growers

Constraints faced by the flower growers were ascertained and are presented in Table 4.

Table 4.

Constraints faced by the Flower Growers

$(n=84)$

\begin{tabular}{|c|l|c|c|}
\hline Sl. No & lonstraints & Total & Percentage \\
\hline 1 & Price fixation by intermediaries & 58 & 69.05 \\
\hline 2 & Lesser availability and high cost of seed material & 53 & 63.10 \\
\hline 3 & Lesser remuneration & 39 & 46.43 \\
\hline 4 & Incidence of pests and diseases & 32 & 38.10 \\
\hline 5 & Lack of awareness about newer techniques & 28 & 33.33 \\
\hline 6 & High Labour requirement & 24 & 28.57 \\
\hline 7 & Perishability & 42 & 50.00 \\
\hline
\end{tabular}


It was observed that in Kanyakumari district price fixation by intermediaries and lesser share to the producers were the major constraints faced by the farmers in the district. The farmers did not sell the produce to consumers directly instead, they were forced to depend on the commission agents cum wholesalers for marketing the flowers. Even though some farmers got advance money from the commission agents, they were forced to sell with high percentage of commission. Lesser availability and high cost of seed materials was another major constraint expressed by the farmers of Tirunelveli district. The seed material for jasmine has to be received from Ramnad which was at a distance place for the farmers. The farmers had to apply pesticides indiscriminately due to the incidence of pest and diseases in jasmine every week. The pesticide was recommended by the local dealers which increases the cost of cultivation. The other important constraint given by the farmers in both the districts was that they received lesser remuneration even after involvement of family labour. Incidence of pest and disease, lack of awareness about newer techniques are also faced by the farmers. Harvesting of the flowers requires labour almost every day and requires labour services only two to three hours per day in the early morning. This makes the non-availability of full day employment and labour should find employment from the other sources after harvesting of flowers. However, a study conducted by Sivashankar and Shashidhar (2011) in Bellary district of Karnataka found that maximum number of farmers indicated the main constraints in production, marketing and credit in cultivation for jasmine flowers.

Constraints faced by traders were, the perishable nature of the commodity that needs quick selling and fetching less price due to price fluctuation. Other major constraints reported were high charges of transportation, spoilage, lack of grading and storage facilities.

There was a remarkable increase in flower cultivation in the districts of Kanyakumari and Tirunelveli in Tamil Nadu. In Kanyakumari district, the area under Nerium had increased by 15.5 per cent due to lesser cost of cultivation, lesser perishability and flowering throughout the year. More than half of the flowers farmers were in practice of pruning which was very important in increasing the yield of flowers. Mostly this was done in crops like jasmine and rose. In Kanyakumari district it was observed that price fixation by intermediaries and lesser share to the producers were the major constraints faced by the farmers in the district. In Tirunelveli district the farmers had got the seed material from Ramnad which was at a distance place for the farmers. They also applied pesticides indiscriminately on jasmine every week. The knowledge level of flower growers could be improved by providing trainings on newer techniques in flower production and minimizing production and marketing constraints for developing efficient and effective value chain in flower production system for the southern districts of Tamil Nadu. 
Trends and Technological Skills Assessment of Flower Cultivation in the Southern Districts of Tamil Nadu

\section{REFERENCES}

Bagyajanani, P, Premavathi, R \& Sivashankar, N., \& Shahidhar, K. K. (2011). Prathap,D.P.(2016). Technology adoption behavior of Jasmine glovers - A critical analysis Journal of Extension Education Adoption behavior of Jasmine cultivation in Bellary district. Indian Research Journal of 28(1). 